\title{
Pengaruh Minat Masyarakat Terhadap Produk British Propolis
}

\author{
Sri Laksmi Pardanawati ${ }^{1)}$, Fandy Tri Apriyono ${ }^{2)}$ \\ ${ }^{1}$ Program Study Akuntansi/ ITB-AAS Indonesia Surakarta \\ ${ }^{2}$ Program Study Ekonomi Syariah/ ITB-AAS Indonesia Surakarta \\ *Email korespondensi: 1aksmi.stie.aas@gmail.com
}

\begin{abstract}
This study aims to determine what factors influence consumer purchase interest in British propolis products among students and lecturers of ITB AAS Surakarta. The variable consists of 4 independent variables (independent), namely product information, prices, promotions and business opportunities. This study uses a quantitative approach with data collection methods carried out through instruments or questionnaires distributed online to students and lecturers of ITB AAS Surakarta. The samples taken were as many as 92 respondents with the system. The data obtained were then processed using the SPSS version 23 application. This analysis used the validity test, reliability test, multiple linear regression test, statistical test through the $T$ test, $F$ count and the coefficient of determination (R2). The results of the t test show that product information has a significant effect on purchase intention, while price, promotion and business opportunities partially do not have a significant effect on consumer buying interest. The results of the F-test show that product information, prices, promotions and business opportunities simultaneously have a significant effect on consumer buying interest. While the R2 test results show that product information, prices, promotions and business opportunities significantly influence consumer buying interest with an effect of $39.8 \%$. While the remaining $60.2 \%$ is influenced by other variables outside this model.
\end{abstract}

Keywords: Product, Price, Promotion, Business Opportunities, Consumer Purchase Interest

Saran sitasi: Pardanawati, S. L., \& Apriyono, F. T. (2021). Pengaruh Minat Masyarakat Terhadap Produk British Propolis. Jurnal Akuntansi dan Pajak, 21 (2), 398-404. doi: http://dx.doi.org/10.29040/jap.v21i2.1673

DOI: http://dx.doi.org/10.29040/jap.v21i2.1673

\section{PENDAHULUAN}

Propolis adalah salah satu produk herbal atau suplemen kesehatan alami dan Propolis juga merupakan zat yang dihasilkan lebah yang berasal dari sari pati tumbuhan. Salah satu produk Propolis yang saat ini sedang mulai banyak di cari yaitu British Propolis. British Propolis adalah premium product dari Bridlington, East Yorkshire, Inggris. Keunggulan British Propolis dibanding produk propolis lain yaitu memiliki kandungan propolis $100 \%$, kadar flavonoid 3-4 kali lebih tinggi, khasiat terasa dalam 21 hari bahkan memiliki garansi atau jaminandalam 21 hari dalam proses penyembuhan.

Produk British Propolis bukanlah produk yang di distribusikan melalui jasa perusahaan yang kemudian di jual atau didistribusikan kembali. Dalam pendistribusiannya, menggunakan sistem penjualan langsung atau direct selling. Maka Ippho Santosa selaku founder dan owner British Propolis membuka kesempatan bagi masyarakat yang ingin bermitra sebagai agen, tetapi masih banyak masyarakat awam yang belum mengenal produk British Propolis dan sayangnya masih banyak masyarakat yang belum memahami pentingnya menjaga kesehatan. Pada waktu mendistribusikan produk British Propolis banyak sekali tanggapan dari masyarakat. Karakter setiap orang berbeda-beda, ini merupakan salah satu kegelisahan yang dirasakan oleh tenaga pemasar.

Masih banyaknya masyarakat yang awam mengenai produk British Propolis menjadi salah satu peluang untuk memperkenalkan produk British Propolis, khususnya di lingkungan kampus ITB AAS Indonesia Surakarta.

\section{Produk}

Menurut Supranto dkk (2011), produk adalah apa saja yang dapat dibutuhkan dan diinginkan oleh konsumen untuk memenuhi kebutuhan yang dipersepsikan. Sedangkan menurut Adisaputro (2014) 
yaitu segala sesuatu yang dapat diamati, disukai dan dibeli untuk memuaskan kebutuhan atau keinginan. Menurut Kotler dan Amstrong (2001) produk adalah "Segala sesuatu yang dapat ditawarkan ke pasar untuk mendapatkan perhatian, dibeli, digunakan, atau dikonsumsi yang dapat memuaskan keinginan atau kebutuhan. Di dalam produk sendiri terdapat beberapa hal perlu di ketahui oleh calon konsumen, yaitu :

a. Pengertian atau definisi produk British Propolis.

b. Kualitas produk, adalah kemampuan suatu produk dalam menjalankan fungsi dan kinerjanya untuk dapat memenuhi kebutuhan dan keinginan pelanggan (Kotler dan Amstrong, 2004). Dalam hal ini, kualitas produkmenjelaskan tentang khasiat dari produk British Propolis.

c. Manfaat produk dapat diartikan sebagai nilai yang diberikan dari suatu produk kepada konsumen. Testimoni konsumen yang sudah membuktikan merupakan feedback dari manfaat yang dirasakan.

d. Jaminan produk, dalam hal ini, produk British Propolis memberi jaminan adanya perubahan kesehatan setelah mengkonsumsi dalam 21 hari.

e. Kemasan produk merupakan bagian luar sebagai pembungkus yang berfungsi sebagai pelindung suatu barang. Kemasan yang baik mampu mempengaruhi ketertarikan konsumen.

f. Label produk, merupakan bagian dari produk yang mempresentasikan suatu informasi, baik berupa gambar maupun kata-kata. Dalam hal ini label yang ada pada kemasan British Propolis meliputi izin BPOM dan sertifikat Halal MUI dan Halal internasional.

g. Endorsment produk, sebagai kegiatan yang dilakukan dalam mensupport suatu produk oleh kalangan tertentu. Produk British Propolis di endorse oleh para artis, ustad, dan tokoh Indonesia.

\section{Harga}

Harga adalah kesepakatan nilai yang menjadi persayaratan bagi pertukaran dalam sebuah transaksi pembelian (Satria, 2017). Pengertian lain, harga diartikan sebagai sesuatu yang harus dikeluarkan pembeli untuk menerima suatu produk (Tjiptono, 2012). Indikator harga adalah (Rangkuti, 2011) :

a. Penilaian mengenai harga secara keseluruhan, harga yang telah ditetapkan oleh perusahaan dapat dianalisa dengan melihat tanggapan yang diberikan konsumen terhadap harga tersebut, apakah konsumen sudah menerima harga yang ditetapkan dengan manfaat yang diterima. b. Respons terhadap kenaikan harga, jika terjadi kenaikan harga dari sebuah produk, sebaiknya diperhatikan bagaimana respon konsumen terhadap kenaikan produk tersebut.

c. Harga dari suatu produk tertentu dibandingkan dengan produk yang sama jika ditempat lain.

Sedangkan menurut Kotler dan Armstrong (2008), ada 4 indikator yang mencirikan harga adalah keterjangkauan harga, kesesuaian harga dengan kualitas produk, daya saing harga, kesesuaian harga dengan manfaat.

\section{Promosi}

Promosi merupakan suatu kegiatan pemasaran yang menjadi faktor penting bagi perusahaan dalam upaya mempertahankan kontinuitas serta meningkatkan kualitas penjualan (Nainggolan dkk, 2018). Swastha (2009) berpendapat bahwa promosi dipandang sebagai kegiatan komunikasi pembeli dan penjual dan merupakan kegiatan yang membantu dalam pengambilan keputusan di bidang pemasaran serta mengarahkan dan menyadarkan semua pihak untuk berbuat lebih baik. Sedangkan promosi penjualan adalah kegiatan pemasaran yang mendorong pembelian dari konsumen dan efektivitas dari pengecer (Mawarsari, 2018).

Tujuan utama promosi adalah menginformasikan, mempengaruhi dan membujuk serta mengingatkan pelanggan sasaran tentang pemasaran dan bauran pemasaran.

Ada 4 elemen promosi (Putri dan Safri, 2015), yaitu (a) Periklanan (Advertising), (b) Tenaga penjual (Personal Selling), (c) Promosi Penjualan (Sales Promotion), (d) Publisitas (Publicity)

\section{Peluang Usaha}

Peluang usaha merupakan suatu bidang kebutuhan pembeli dimana seorang wirausaha dapat mengelola usaha di bidang yang di tekuninya dengan mendapatkan keuntungan. Pengertian lain,

Peluang usaha merupakan kesempatan atau waktu yang tepat untuk dimanfaatkan atau diambil bagi seorang wirausahawan untuk mendapatkan keuntungan (Kurniati, 2017)

\section{Minat Beli Konsumen}

Minat adalah sesuatu yang pribadi dan berhubungan dengan sikap (Simamora, 2002). Menurut Kotler dkk (2009), minat beli adalah suatu perilaku konsumen yang muncul sebagai respon terhadap objek yang menunjukkan keinginan pelanggan untuk melakukan pembelian. Swastha dan Irawanmengemukakan faktor-faktor yang 
mempengaruhi minat membeli berkaitan dengan perasaan dan emosi, jika seseorang merasa senang dan puas dalam membeli barang atau jasa, maka hal tersebut akan memperkuat minat membeli, sedangkan ketidakpuasan biasanya akan menghilangkan minat (Satria, 2017). Minat beli dapat diidentifikasikan melalui indikator sebagai berikut (Kotler dkk, 2010):

a. Minat transaksional, yaitu kecenderungan seseorang untuk memembli produk.

b. Minat refrensial, yaitu kecenderungan seseorang mereferensikan produk kepadaorang lainmereferensikan produk kepada orang lain

c. Minat prefrensial, yaitu minat yang menggambarkan perilaku seseorang yang memiliki prefrensi utama pada produk tersebut.

d. Minat eksploratif, yaitu minat yang menggambarkan perilaku seseorangyang selalu mencari informasi mengenai produk yang diminatinya serta mencari informasi untuk mendukung sifat-sifat positif dari produk tersebut.

\section{Kerangka Pemikiran}

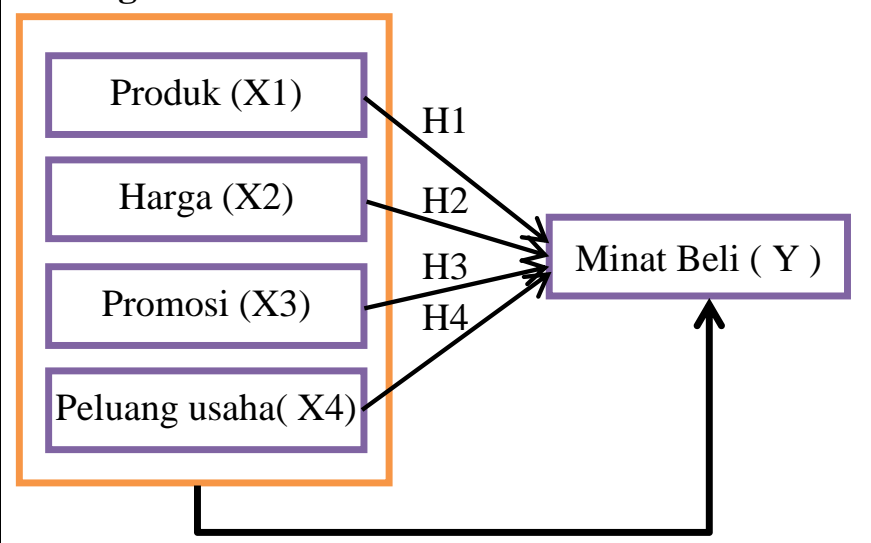

Gambar 1 : Kerangka pemikiran

Hipotesis dalam penelitian ini adalah:

H1 : Produk berpengaruh signifikan terhadap minat beli konsumen

H2 : Harga berpengaruh significan terhadap minat beli konsumen

H3 : Promosi berpengaruh signifikan terhadap minat beli konsumen

H4 : Peluang usaha berpengaruh signifikan terhadap minat beli konsumen

H5 : Informasi Harga, Promosi dan Peluang Usaha berpengaruh Signifikan secara simultan terhadap minat beli konsumen.

\section{METODE PENELITIAN}

\section{Jenis Penelitian}

Dalam penelitian ini metode penelitian yang digunakan yaitu penelitian kuantitatif. Metode kuantitatif yaitu data yang berbentuk angka atau bilangan (Mustofa, 2013)

\section{Waktu dan Tempat Penelitian}

Waktu penelitian dimulai dari penyusunan usulan penelitian sampai dengan terlaksana laporan penelitian ini, yakni pada bulan Maret 2020 sampai bulan Juni 2020. Penelitian dilaksanakan di Kampus ITB AAS Indonesia Surakarta pada segenap Mahasiswa yang aktif dan dosen tetap

\section{Populasi}

Populasi penelitian ini adalah Mahasiswa dan Dosen yang aktif di lingkungan kampus ITB AAS Indonesia. Data yang diperoleh yaitu jumlah populasi Mahasiswa yang aktif sejumlah 1189 orang, sedangkan jumlah populasi dosen tetap yang aktif sebanyak 32 orang. Maka total jumlah populasi penelitian sebanyak 1221.

\section{Sampel}

Sugiyono (2017) Simple Random Sampling adalah pengambilan anggota sampel dari populasi yang dilakukan secara acak tanpa memperhatikan strata yang ada dalam populasi itu. Jumalh sampel pada penelitian ini ada 92 orang.

\section{Teknik pengumpulan data}

Teknik yang digunakan dalam mengumpulkan data pada penelitian ini terdiri dari beberapa cara, diantaranya : (a) kuesioner, (b) wawancara, (c) dokumentasi

\section{Instrumen Penelitian}

Instrumen penelitian merupakan alat yang digunakan oleh peneliti untuk mengumpulkan data yang diteliti. Dalam penelitian ini, metode pengumpulan data yang digunakan yaitu menggunakan Kuesioner. Dalam hal ini menggunakan teknik skala likert. Sugiyono (2014) berpendapat bahwa Skala Likert digunakan untuk mengukur suatu sikap, pendapat dan persepsi seseorang atausekelompok orang mengenai suatu fenomena sosial.

\section{Variabel Penelitian}

Variabel dependen (terikat) adalah variabel yang diakibatkan atau dipengaruhi oleh variabel independen. Variabel dependen dalam penelitian ini adalah Minat Membelisebagai Y. Sedangkan Variabel Independen (bebas) adalah variabel yang mempengaruhi atau yang menjadi sebab timbulnya variabel dependen (terikat). Dalam penelitian ini, yang merupakan variabel bebas adalahProduk sebagai X1, Harga sebagai $\mathrm{X}_{2}$, Promosi sebagai $\mathrm{X}_{3}$, dan Peluang usaha sebagai $\mathrm{X} 4$. 


\section{HASIL DAN PEMBAHASAN}

\subsection{Hasil Penelitian}

\section{a. Hasil Uji Validitas}

Hasil sekelompok orang mengenai suatu fenomena sosial.

\section{Variabel Penelitian}

Variabel dependen (terikat) adalah variabel yang diakibatkan atau dipengaruhi oleh variabel independen. Variabel dependen dalam penelitian ini adalah Minat Membelisebagai Y. Sedangkan Variabel Independen (bebas) adalah variabel yang mempengaruhi atau yang menjadi sebab timbulnya variabel dependen (terikat). Dalam penelitian ini, yang merupakan variabel bebas adalah Produk sebagai X1,
Harga sebagai $\mathrm{X}_{2}$, Promosi sebagai $\mathrm{X}_{3}$, dan Peluang usaha sebagai $\mathrm{X} 4$.

Pengujian validitas seluruh variabel independen (X) menunjukkan nilai setiap pertanyaan seluruh variabel mempunyai $r$ hitung $>r$ tabel $(>0,197)$ maka dapat disimpulkan bahwa keseluruhan indikator pertanyaan tersebut adalah valid

\section{b. Hasil Uji Reliabilitas}

Hasil uji reliabilitas menunjukkan bahwa seluruh instrumen dalam penelitian ini reliabel atau dapat diterima. karena nilai $\mathrm{r}$ alpha lebih besar dari 0,6. Semua hasil uji berada pada nilai di atas 0,80 maka tergolong reliabilitas kuat.

\section{c. Hasil Uji Regresi Linear Berganda}

Tabel. 1 Hasil Uji Regresi Linear Berganda

Coefficients $^{\mathbf{a}}$

\begin{tabular}{|c|c|c|c|c|c|c|}
\hline \multirow{2}{*}{\multicolumn{2}{|c|}{ Model }} & \multicolumn{2}{|c|}{ Unstandardized Coefficients } & \multirow{2}{*}{$\begin{array}{c}\text { Standardized Coefficients } \\
\text { Beta }\end{array}$} & \multirow[b]{2}{*}{$\mathrm{T}$} & \multirow[b]{2}{*}{ Sig. } \\
\hline & & B & Std. Error & & & \\
\hline \multirow[t]{5}{*}{1} & (Constant) & 0,759 & 1,681 & & 0,452 & 0,653 \\
\hline & Produk & 0,210 & 0,098 & 0,279 & 2,146 & 0,035 \\
\hline & Harga & 0,145 & 0,130 & 0,139 & 1,113 & 0,269 \\
\hline & Promo & 0,078 & 0,178 & 0,058 & 0,440 & 0,661 \\
\hline & pel_ush & 0,225 & 0,126 & 0,239 & 1,786 & 0,078 \\
\hline
\end{tabular}

a. Dependent Variable: minat

Sumber : Data primer yang diolah 2020

Dari persamaan regresi diatas maka dapat diketahui bahwa koefisien regresi informasi produk (b1), harga (b2), promosi (b3), dan peluangusaha (b4) mempunyai koefisien regresi positif. Hal tersebut menunjukkan bahwa semua variabel independen $(\mathrm{X})$ memiliki pengaruh secara positif terhadap variabel dependen $(\mathrm{Y})$.

d. Hasil Uji Parsial (Uji t)

Tabel 2. Hasil Uji Parsial (Uji t)

\begin{tabular}{|c|c|c|c|c|c|c|}
\hline \multirow{2}{*}{\multicolumn{2}{|c|}{ Model }} & \multicolumn{2}{|c|}{ Unstandardized Coefficients } & \multirow{2}{*}{$\frac{\text { Standardized Coefficients }}{\text { Beta }}$} & \multirow[b]{2}{*}{$\mathrm{t}$} & \multirow[b]{2}{*}{ Sig. } \\
\hline & & $\mathrm{B}$ & Std. Error & & & \\
\hline \multirow[t]{5}{*}{1} & (Constant) & 0,759 & 1,681 & & 0,452 & 0,653 \\
\hline & Produk & 0,210 & 0,098 & 0,279 & 2,146 & 0,035 \\
\hline & Harga & 0,145 & 0,130 & 0,139 & 1,113 & 0,269 \\
\hline & Promo & 0,078 & 0,178 & 0,058 & , 440 & 0,661 \\
\hline & pel_ush & 0,225 & 0,126 & 0,239 & 1,786 & 0,078 \\
\hline
\end{tabular}

a. Dependent Variable: minat

Sumber : Data primer yang diolah 2020

Dari hasil pengujian parsial (uji t) sesuai tabel 2, maka dapat diperoleh kesimpulan sebagai berikut :

1) Pengaruh Produk terhadap Minat Beli Konsumen. Nilai t hitung variabel Produk pada tabel 2 adalah 2,146, dimana lebih besar dari t tabel $(2,146>$ $1,987)$. Dan nilai probabilitas 0,035 dimana 0,035
$<0,05$. Sehingga Ho ditolak dan Ha diterima, yang artinya bahwa variabel produk berpengaruh secara signifikan terhadap variabel minat beli konsumen.

2) Pengaruh Harga terhadap Minat Beli Konsumen. 
Nilai t hitung variabel Harga pada tabel 2 adalah 1,113 dimana lebih kecil dari $\mathrm{t}$ tabel $(1,113<$ 1,982). Dan nilai probabilitas 0,269 dimana 0,269 $>0,05$. Sehingga Ho diterima, dan Ha ditolak, yang artinya variabel Harga tidak berpengaruh signifikan terhadap variabel Minat beli konsumen.

3) Pengaruh Promosi terhadap Minat Beli Konsumen Nilai t hitung variabel Promosi pada tabel 2 adalah 0,440 dimana lebih kecil dari $\mathrm{t}$ tabel $(0,440<$ 1,987). Dan nilai probabilitas 0,661 dimana 0,661>0,05. Sehingga Ho diterima, dan Ha ditolak, yang artinya variabel Promosi tidak berpengaruh signifikan terhadap Minat beli konsumen.

4) Pengaruh Peluang Usaha terhadap Minat Beli Konsumen

Nilai t hitung variabel Peluang Usaha pada tabel 2 adalah 1,786 dimana lebih kecil dari t tabel $(1,786$ $<$ 1,987). Dan nilai probabilitas 0,078 dimana $0,078>0,05$. Sehingga Ho diterima, dan $\mathrm{Ha}$ ditolak, yang artinya variabel Peluang usaha tidak berpengaruh signifikan terhadap minat beli konsumen.

\section{e. Hasil Uji Simultan (Uji F)}

\section{Tabel 3. Hasil Uji Simultan (Uji F)}

\begin{tabular}{|l|r|r|r|c|l|}
\hline \multicolumn{1}{|c|}{ Model } & $\begin{array}{c}\text { Sum of } \\
\text { Squares }\end{array}$ & Df & $\begin{array}{c}\text { Mean } \\
\text { Square }\end{array}$ & F & Sig. \\
\hline 1 Regression & 258,879 & 4 & 64,720 & 14,401 & $0,000^{b}$ \\
Residual & 390,990 & 87 & 4,494 & & \\
Total & 649,870 & 91 & & & \\
\hline
\end{tabular}

Sumber : Data primer yang diolah 2020

Dari hasil uji F sesuai tabel 3 diatas, nilai F hitung lebih besar dari $\mathrm{F}$ tabel $(14,401>2,476)$. Dan nilai probabilitas lebih kecil dari sig F $(0,00<0,05)$, maka dapat diambil kesimpulan bahwa variabel independen (produk, harga, produk, dan peluang usaha) secara bersama-sama berpengaruh positif serta signifikan terhadap variabel dependen yaitu minat beli.

\section{f. Hasil Uji Koefisien Determinasi}

Tabel 4. Hasil Uji Koefisien Determinasi

\begin{tabular}{|l|c|r|r|r|}
\hline Model & $\mathrm{R}$ & $\begin{array}{c}\mathrm{R} \\
\text { Square }\end{array}$ & $\begin{array}{c}\text { Adjusted } \\
\text { R Square }\end{array}$ & $\begin{array}{c}\text { Std. Error of } \\
\text { the Estimate }\end{array}$ \\
\hline 1 & $0,631^{\mathrm{a}}$ & 0,398 & 0,371 & 2,11994 \\
\hline
\end{tabular}

Berdasarkan hasil analisis data pada tabel 4.17 nilai $\mathrm{R}=0,631$ atau adjusted $\mathrm{R}=0,371$. Artinya, bahwa hasil uji koefisien determinasi menjelaskanbahwa variabel produk (X1), harga (X2), promosi (X3) dan peluang usaha (X4) dapat mempengaruhi minat untuk membeli produk British Propolis pada mahasiswa dan dosen di ITB AAS Indonesia sebesar $37,1 \%$. Sedangkan sisanya (100 $39,8)=62,9 \%$ dipengaruhi oleh variabel lain yang tidak terdapat dalam model regresi linier tersebut.

\subsection{Pembahasan}

Persamaan regresi Minat Beli $=0,759+0,210$ Info produk $+0,145$ Harga + 0,078 Promosi $+0,225$ Peluang Usaha tersebut menunjukkan bahwa variabel produk (X1), harga (X2), promosi (X3), dan peluang usaha (X4) memiliki pengaruh secara positif terhadap minat beli konsumen (Y). Selanjutnya, berdasarkan analisis uji Parsial (uji t) didapat kesimpulan sebagai berikut :

a. H1: Produk berpengaruh signifikan terhadap minat beli konsumen.

Hipotesis diatas terbukti, sesuai dengan hasil uji $\mathrm{t}$, yaitu dimana $\mathrm{t}$ hitung lebih besar dari t tabel $(2,146>1,66)$. Maka Ho ditolak, dan Ha diterima. Artinya ada pengaruh positif variabel Informasi produk terhadap variabel minat beli. Serta nilai probabilitas lebih kecil dari nilai signifikan $(0,035<0,05)$, yang artinya signifikan. Maka dapat disimpulkan bahwa seputar informasi mengenai produk British Propolis mampu mempengaruhi secara signifikan terhadap minat untuk membeli produk British Propolis pada mahasiswa dan dosen di kampus ITB AAS Indonesia. Penelitian ini sesuai dengan penelitian yang dilakukan oleh Nora Pitri Nainggolan dan Heryenzus (2018) dimana variabel kualitas produk memiliki pengaruh yang positif dan signifikan terhadap variabel minat beli konsumen.

b. H2 : Harga berpengaruh signifikan terhadap minat beli konsumen.

Hipotesa diatas tidak terbukti. Karena berdasarkan hasil uji parsial, $\mathrm{t}$ hitung lebih kecil dati $\mathrm{t}$ tabel $(1,113<1,66)$. Maka Maka Ho diterima, dan Ha ditolak. Artinya variabel harga tidak berpengaruh terhadap variabel minat beli. Serta nilai probabilitas lebih besar dari signifikan $(0,269>0,05)$ yang artinya tidak ada pengaruh yang signifikan. Maka, dapat diambil kesimpulan bahwa harga tidak berpengaruh signifikan terhadap minat untuk membeli produk British Propolis pada mahasiswa dan dosen di kampus 
ITB AAS Indonesia. Penelitian ini berlawanan dengan penelitian terdahulu (Kumalasari, 2019; Mawarsari, 2018; Nainggolan dan Heryenzus, 2018; Satria, 2017; Utami dan Saputra, 2017; Ma'munah, 2017; Razak, 2016) yang kesemuanya berasumsi bahwa harga berpengaruh positif dan signifikan terhadap minat beli konsumen.

c. H3: Promosi berpengaruh signifikan terhadap minat beli konsumen.

Hipotesa diatas tidak terbukti. Karena berdasarkan hasil uji t, dimana t hitung lebih kecil dati $t$ tabel $(0,040<1,987)$. Maka Maka Ho diterima, dan Ha ditolak. Artinya variabel harga tidak berpengaruh terhadap variabel minat beli. Serta nilai probabilitas lebih besar dari signifikan $(0,661>0,05)$ yang artinya tidak ada pengaruh yang signifikan. Maka, dapat diambil kesimpulan bahwa promosi tidak berpengaruh signifikan terhadap minat untuk membeli produk British Propolis pada mahasiswa dan dosen di kampus ITB AAS Indonesia. Penelitian ini berlawanan dengan penelitian terdahulu (Kumalasari, 2019; Mawarsari, 2018; Nainggolan dan Heryenzus, 2018; Satria, 2017; Utami dan Saputra, 2017; Ma'munah, 2017; Razak, 2016) yang kesemuanya berasumsi bahwa promosi berpengaruh positif dan signifikan terhadap minat beli konsumen.

d. H4: Peluang usaha berpengaruh signifikan terhadap minat beli konsumen.

Hipotesis diatas tidak terbukti. Karena dari hasil uji t, yaitu dimana $t$ hitung lebih kecil dari $t$ tabel $(1,786<1,987)$. Maka Maka Ho diterima, dan Ha ditolak. Artinya variabel peluang usaha berpengaruh terhadap variabel minat beli. Namun, nilai probabilitas lebih besar dari nilai signifikan $(0,078>0,05)$, yang artinya tidak signifikan. Maka dapat disiimpulkan bahwa peluang usaha tidak berpengaruh signifikan terhadap minat untuk membeli produk British Propolis pada mahasiswa dan dosen di kampus ITB AAS Indonesia.

Dari keempaat variabel tersebut yang paling dominan pengaruhnya terhadap variabel minat beli adalah variabel informasi produk. Meski hasil uji simultah $\mathrm{n}$ (uji $\mathrm{F}$ ) menyatakan bahwa keempat variabel independen secara bersama-sama berpengaruh positif serta signifikan terhadap variabel dependen, namun salah 1 variabel yang sangat dominan pengaruh nya serta berpengaruh sangat signifikan yaitu produk. Dapat ditarik suatu pendapat, bahwa para mahasiswa dan dosen di kampus ITB AAS Indonesia setelah mengetahui produk British Propolis, baik berupa khasiat / manfaat, kemasan, legalitas, testimoni ataupun endorsemen, berpeluang untuk minat membeli produk British Propolis.

\section{KESIMPULAN}

Berdasarkan analisis data serta pembahasan diatas, maka dapat diambil kesimpulan sebagai berikut:

a. Hasil dari uji parsial, dapat dianalisa bahwa variabel Produk berpengaruh signifikan terhadap minat beli konsumen. Sedangkan untuk variabel Harga, Promosi dan Peluang Usaha secara parsial tidak berpengaruh signifikan terhadap minat beli konsumen.

b. Hasil dari uji simultan, dapat dianalisa bahwa variabel independen (informasi, produk, harga, produk, dan peluang usaha) secara bersama-sama berpengaruh positif serta signifikan terhadap variabel dependen yaitu minat beli konsumen.

c. Berdasarkan hasil uji koefisien determinasi $\mathrm{R}^{2}(\mathrm{R}$ Square $)=0,398$. Analisanya yaitu variabel produk (X1), harga (X2), promosi (X3) dan peluang usaha (X4) dapat mempengaruhi minat beli konsumen $39,8 \%$. Sedangkan sisanya yang $60,2 \%$ dipengaruhi oleh variabel lain yang tidak terdapat dalam model regresi linier tersebut.

\section{UCAPAN TERIMA KASIH}

Diucapkan terima kasih kepada segenap keluarga besar ITB AAS Indonesia Surakarta atas dukungannya dalam menyelesaikan penelitian ini, khususnya kepada segenap Mahasiswa dan Dosen ITB AAS Indonesia.

\section{REFERENSI}

Adisaputro, G. 2014. Manajemen Pemasaran. Yogyakarta : UPP STIM YKPN

Aprilianty, Eka. 2012. Pengaruh Kepribadian Wirausaha, Pengetahuan Kewirausahaan, Dan Lingkungan Terhadap Minat Berwirausaha Siswa SMK. Jurnal Pendidikan Vokasi, 2(3)

Ghozali, Imam. 2013. Aplikasi Analisis Multivariate dengan Program SPPS.Edisi ketujuh.Semarang: Badan Penerbit Universitas Diponegoro.

Kotler, Philip dan Armstrong. 2001. Prinsip-prinsip Pemasaran. Jakarta : Erlangga. 
Kotler, Philip dan Armstrong, Gery. 2004. Dasardasar Pemasaran. Jakarta : PT Indeks

Kotler, P. Dan Keller, K. 2010. Manajemen Pemasaran. Jakarta : Erlangga

Kurniati, A. Mila. 2017. Analisis Peluang Usaha Komoditas Hortikultura

Mawarsari, Intan. 2018. Pengaruh kualitas Produk, Harga dan Promosi Terhadap Minat Beli Ulang Konsumen Olahan Buah Carica di Daerah Wonosobo. Skripsi. Tidak diterbitkan. Fakultas Ekonomi. Universitas Sanata Dharma : Yogyakarta.
Mustofa, Bisri. 2015. Psikologi Pendidikan. Parama Ilmu : Yogyakarta.

Nainggolan, N.P., Heryenzus. 2018. Analisis FaktorFaktor yag Mempengaruh Minat Beli Konsumen Dalam Membeli Rumah di Kota Batam. Jurnal Ilmah Manajemen dan Bisinis, 19(1) 